\title{
Extent of Formalin and Cane Sugar Adulteration and its Impact on Physicochemical Attributes of Milk Sold at Hyderabad and its Outskirts
}

\author{
Nida Shaikh ${ }^{1}$, Asadullah Marri², Barkatullah Qureshi ${ }^{3}$, Mubeena Pathan ${ }^{4}$, Velo Suthar ${ }^{5}$, \\ Naeem Ahmed Qureshi ${ }^{6}$, Bhai Khan Solangi ${ }^{7}$, Veena Kumari ${ }^{8}$ \\ ${ }^{1,2}$ Institute of Food Sciences \& Technology, Sindh Agriculture University, Tandojam \\ ${ }^{3,4}$ Information Technology Centre, Sindh Agriculture University, Tandojam \\ ${ }^{5,6}$ Department of Statistics, Sindh Agriculture University, Tandojam \\ ${ }^{7}$ Department of Entomology, Sindh Agriculture University, Tandojam \\ ${ }^{8}$ Department of Sociology, University of Sindh, Jamshoro
}

\begin{abstract}
The present investigation was made to examine the extent of adulteration of formalin, cane sugar, boric acid, detergent and salt in market milk. The subsequent impact of these adulterants on the physicochemical attributes of market milk sold at Hyderabad and its outskirts was also studied. For this reason, twenty unprocessed market milk samples were randomly collected from different dairy shops of the Hyderabad city (A). A similar number of samples (twenty) were also availed from the dairy shops of the outskirts of Hyderabad (B). The unprocessed whole buffalo milk/Control milk samples (C) were obtained from the dairy farm of the University. All the samples were immediately brought to the Institute of Food Sciences and Technology, Sindh Agriculture University, Tandojam for analyzing. The results revealed that,75\% of total milk samples collected from Hyderabad city (A)were adulterated with formalin and $60 \%$ with cane sugar. The extent of formalin and cane sugar adulteration remained $65 \%$ and $45 \%$, respectively in milk samples collected from outskirts of Hyderabad (B). However, adulterants like boric acid (0\%), detergent (0\%) and salt (0\%) were not found in any of the sample from both areas $(A$ and $B)$.There were significant differences $(P<0.05)$ obtained in the present data regarding physicochemical attributes(such as $\mathrm{pH}$, titratable acidity, specific gravity, protein and fat content) between the control (C) and market milk samples (A and B). It was also observed from this study that all the physicochemical properties remained significantly higher for the market milk samples availed from outskirts of Hyderabad (B) than that of Hyderabad city (A).
\end{abstract}

Keywords: Adulteration, formalin, cane sugar and physicochemical attributes

\section{Introduction}

Milk is an integral part of human diet. It contains almost all essential nutrients like protein, lactose, fats, minerals and vitamins in an appropriate or balanced proportion (Neumann et al., 2002 and Singuluri\&Sukumaran, 2014). In milk,more than 100 substances are present either in solution, suspension or as emulsion in its water phase(Altaf, 2007; Ali, 2011 and Kandpal, 2012).According to food guide pyramid, it is recommended for an adult to consume 2-3 servings of dairy based food commodities in a day forbetter health and maintenance of life.

Wholesomemilk is the choice of everyconsumer. Quality of milk can be only maintained by securing its purity and cleanliness. Good quality milk is needed for quality dairy items (Nirwal et al., 2013) and for better health of consumer.Unfortunately, milk is the most adulterated food commodity especially in the developing countries. Adulteration of milk is one of the severeconcerns that the dairy sector of Pakistan is facing recent days, which not only causing major economic losses for the dairyindustries but is health threatening call as well for consumers (Barham et al., 2014). Overpopulation, scattered colonization and rapid urbanization are the few main factors increasing the demand of milk production (Adeelaet al., 2014). Milk dealers are often found to involve in milk adulteration to meet the linkage between demand and supply of milk.Adulteration of milk is a malpractice in which dealers either incorporate cheap substances or subtract valuable components from milk to increase its volume and thus profit margin (Lateef et al., 2009). Excessively documented adulterants used to adulterate milk arediluent (water and ice)thickening agents (starch, glucose, urea, flour, salt and chlorine etc.), preservatives (formalin, sodium bicarbonate and sodium carbonate etc.), reconstituting agents (seed oils, cane sugar andanimal fats and milk powder), cosmetic agents (Detergent/soap and bleaching powder etc.)and others (Walker et al., 2004; Tipu et al., 2007 and Singuluri \&Sukumaran, 2014).

Formalin is a potentially hazardous toxic or injurious substance. It is a potent carcinogen (Gwin et al., 2009). Formalin isused to adulterate milk in order to neutralize milk ortoincrease its shelf life.Consumption of an elevated dose of formalin can cause vomiting, abdominal pain and diarrhea. It may also disturb the optic nerves and may cause blindness. Boric acid causes nausea, vomiting, diarrhea, kidney damage, acute failure of circulatory system and even death (Beall and Scofield, 1995; Mota et al., 2003; Haasnoot et al., 2004; Saad et al., 2005;Ayub et al., 2007; Rideout et al., 2008; Gwin et al., 2009; Li et al., 2009 and See et al.,2010).Detergents are added in milk to emulsify and dissolve the oil in water phase giving a frothy appearance, characteristic white color or to enhance the cosmetic nature 


\section{International Journal of Science and Research (IJSR) \\ ISSN (Online): 2319-7064 \\ Index Copernicus Value (2013): 6.14 | Impact Factor (2015): 6.391}

of milk (Walker, et al., 2004). These detergents maycause gastrointestinal complications(Singuluri \&Sukumaran, 2014). Cane sugar or sucrose is added in the milk to reconstitute its compositional requirement followed by adulteration of extraneous water in the milk. It imparts role in maintaining the characteristic sweet taste of milk which is usually lost by water adulteration.

Keeping in view the deleterious effects of these adulterants, the present study is therefore planned to investigate the extent of adulteration and impact of these adulterants upon physicochemical attributes of market milk sold at Hyderabad and its outskirts

\section{MATERIALS AND METHODS}

\subsection{Sample collection}

Market milk sold at Hyderabad and its adjoining areas was the sample for present study. Twenty unprocessed market milk samples were collected randomly from various dairy shops of the Hyderabad city (A). A similar number of unprocessed milk samples (twenty) were also availed from the dairy shops of adjoining areas of Hyderabad (B). The unprocessedwhole buffalo milkor control samples (C) were obtained from the dairy farm of the university (unadulterated/ free from any adulteration). All the samples were kept in the sterile glass bottles, labelled carefully and immediately brought to the Institute of Food Sciences and Technology, Sindh Agriculture University, Tandojam. Milk samples collected from Hyderabad city (A) and its adjoining areas (B) were used for analyzing the extent of adulteration of formalin, cane sugar, benzoicacid, detergent and salt. The impact of adulteration on physicochemical attributes was also determined. However, control samples were only used to determinetheir physicochemical analysis and these findings were compared with physicochemical properties ofmarket samples of both areas.

\subsection{Methodology}

MAT (Milk Adulteration Testing) kit consisting of reagent bottles for qualitative detection of individual adulterantswas purchased from QOL laboratory, University of Veterinary Sciences, Lahore and was used for determining the extent of adulteration of formalin, cane sugar, boric acid, detergentand salt in market milk samples (A \& B).

All market milk (A \& B) and controlsamples (C) were subjected to determine their physicochemical attributes. Specific gravity, Titratable acidity, $\mathrm{pH}$, fat and protein content were analyzed according to the standard methods of Association of Official Analytical Chemist (AOAC, 2000).

\section{Statistical Analysis}

The data so obtained was analyzed according to statistical procedure of ANOVA, through computerized statistical package (i.e. Student Edition of Statistics Version 8.1).

\section{Results and Discussion}

\subsection{Extent of adulteration in market milk}

The data belonging to extent of adulteration in market milk samples of both areas $(A=$ Hyderabad City and $B=$ Outskirts of Hyderabad) is given in Table 1. Formalin and cane sugar were the common adulterants found in milk samples. Among twenty milk samples from each area, 15 samples (75\%) of Hyderabad city and 13 samples (65\%)from outskirts of Hyderabad were adulterated with formalin. However, 12 samples (60\%) of Hyderabad city and 09 samples (45\%) from outskirts of Hyderabad were adulterated with cane sugar. It was also observed from the study that Boric acid, detergent and salts were not obtained from any of the samples of both areas. Study of Nirwal et al. (2013) shows parallel outcomes with the present data related to the detergent/soap and Boric acid adulteration (0\%) in market milk samples, whilst there was no any single milk sample found to haveadulterated with formalin in his study. The present findings regarding extent of adulteration of formalinagreed with the reports of Singuluri \&Sukumaran (2014)who reported that 16 market milk samples (of Hyderabad, India) adulterated with formalin. Study conducted by Chakravorty and Chakravarty, (2011) also reveals similar interpretations, that milk distributed in different localities of Varanasi city is highly adulterated and impure.

Table 1 Extent of adulteration in market milk sold at Hyderabad (A) and its outskirts (B)

\begin{tabular}{|l|l|l|l|l|l|}
\hline S.no & \multirow{2}{*}{ Adulterants } & \multicolumn{2}{|l|}{$\mathbf{A}$} & \multicolumn{2}{l|}{ B } \\
\cline { 3 - 6 } & & $\#$ & $\mathbf{\%}$ & $\#$ & $\mathbf{\%}$ \\
\hline $\mathbf{1}$ & Formalin & 15 & 75 & 13 & 65 \\
\hline $\mathbf{2}$ & Cane sugar & 12 & 60 & 09 & 45 \\
\hline $\mathbf{3}$ & Boric acid & 00 & 00 & 00 & 00 \\
\hline $\mathbf{4}$ & Detergent & 00 & 00 & 00 & 00 \\
\hline $\mathbf{5}$ & Salt & 00 & 00 & 00 & 00 \\
\hline
\end{tabular}

\# = Numbers of adulterated samples (out of 20 samples)

3.2. Influence of formalin and cane sugar on physicochemical attributes of market milk

Figure 1 reveals the data for average $\mathrm{pH}$ value of milk samples. It was noticed that average $\mathrm{pH}$ value of the market milk samples obtained from Hyderabad city (A) remained significantly higher (i.e. 7.04) than milk samples of outskirts of Hyderabad (B) and control (C) which were 6.97 and 6.74, respectively.This increase in $\mathrm{pH}$ of market milk samples than that of control samples may be due to the extensive use of adulterants in milk. Present results are relativelysimilar with the findings of Nirwal et al., 2013, in which the range of average $\mathrm{pH}$ remained6.7 to 6.9 in the market milk samples of Dehradun.

The findings regarding titratable acidity are presented in Figure 2. The average titratable acidity of the control milk samples (C)was significantly higher and remained 0.18. However, average titratable acidity for market milk samples collected from Hyderabad city (A) and its outskirts (B) stayed 0.15 and 0.14 , respectively. The reason for lower titratable acidity in market milk in comparison to control milk samples may be owing to incorporation of milk preservatives that play key role in mitigating the growth of lactic acid bacteria and thus lactic acid production in milk. Present results for titratable acidity are in line with the findings of Kanwalet al. (2004) who determined titratable acidity $(0.15 \%)$ of market milk. 


\section{International Journal of Science and Research (IJSR) \\ ISSN (Online): 2319-7064 \\ Index Copernicus Value (2013): 6.14 | Impact Factor (2015): 6.391}

Data pertaining to average specific gravity is presented in figure 3 and it shows significantly higher value (i.e. 1.031) for control milk samples (C), whereas, values for average specific gravity of market milk samplesavailed from Hyderabad city (A) and its outskirts (B) remained 1.022 and 1.025 respectively. Average specific gravity of control milk samples was more than that of market milk samples (A \& $\mathrm{B})$; this may be due to the removal of fat/cream/other natural components from the milk. Present findings are in agreement with the findings of Lateefet al. (2009) who observed average specific gravity, which was 1.020 in market milk samples.

Average protein content of the milk samples is revealed in Figure 4. It is shown in this figure that protein content of the control milk samples (C) was significantly higher (i.e. 3.7). However, it remained 2.8 for market milk samples collected from Hyderabad city (A) and 3.07for outskirts of Hyderabad (B). The reason for low protein content in market milk samples may be owing to excessive adulteration practices, however, present findings are relatively analogous with the findings of Mustafa et al. (1991) who determined 2.48\% of protein content in milk samples thatprocessed in canteens of Faisalabad, Pakistan.

Average fat content of the milk samples is given in Figure 5. Control milk samples (C) were found to have significantly higher values (i.e. 6.14). The average fat content for milk samples from Hyderabad (A) was 4.65 and 5.30 for outskirts of Hyderabad (B). Lower fat content in market milk may be due to the separation/removal of fat or cream from market milk.

\section{References}

[1] Ali, A., M. S. Mahmood, L. Hussain and M. Akhtar. 2011. Adulteration and microbiological quality of milk (A Review). Pak J Nutri., 12: 1195-1202.

[2] Altaf, I., M. Ashfaq and S. Saddique. 2007. Handbook published by the Quality Control Laboratory. By Tipu M. S. Lahore: University of Veterinary Animal Sciences 7.

http://www.cnpp.usda.gov/sites/default/files/archived_p rojects/FGPPamphlet.pdf

[3] AOAC. 2000. Dairy Products. In: Official Methods of Analysis. AOAC International, Gaithersburg, Maryland, USA.

[4] Awan, A., M. Naseer, A. Iqbal, M. Ali, R. Iqbal and F. Iqbal. 2014. A study on chemical composition and detection of chemical adulteration in tetra pack milk samples commercially available in Multan. Pakistan journal of pharmaceutical sciences, 27(1):183-6.

[5] Ayub, M., Q. Ahmed, M. Abbas, I. M. Qazi and I. A. Hattak. 2007. Composition and adulteration analysis of milk samples. Sarhad Journal of Agriculture, 23 (4), 1127-1130.

[6] Barham, G. S., M. Khaskheli, A. H. Soomro, Z. A. Nizamani. 2014. Detection and extent of extraneous water anadulteration in milk consumed at Hyderabad. Pakistan Journal of Food and Nutrition Sciences, 2(2): 47-52.

[7] Beall, D. P and R. H. Scofield. 1995. Milk-alkali syndrome associated with calcium carbonate consumption. Reports of seven patients with parathyroid hormone levels and an estimate of prevalence among patients hospitalized with hypocalcaemia. Medicine, 74 (2), 89-96

[8] Chakravorty, S and A. Chakravarty. 2011. An Investigation of adulteration in milk obtained from different localities of Varanasi city. The Indian Journal of Research Anvikshiki, 5: 120-123.

[9] Gwin, M. C., G. Lienert and J. Kennedy. Formaldehyde exposure and asthma in children. A systematic review. Environment Health Perspective, 118, 2009, 313-317.

[10] Haasnoot, W., N. G. Smits, A.E.K. Voncken and M. G. Bremer. 2004. Fast biosensor immunoassays for the detection of cows' milk in the milk of ewes and goats. Journal of Dairy Research, (71), 322-329.

[11] Kandpal, S. D., A. K. Srivastava and K. S. Negi. 2012. Estimation of quality of raw milk (open \& branded) by milk adulteration testing kit. Ind J Community Health, 3: 188-192.3.

[12] Kanwal, R., T. Ahmed and B. Mirza. 2004. Comparative analysis of milk collected from buffalo, cow, goat and sheep of Rawalpindi/Islamabad region in Pakistan. Asian J. Plant Sci., 3:300-305.

[13] Lateef, M., A. Faraz, M. I. Mustafa, P. Akhtar and M. K. Bashir. 2009. Detection of adulterants and chemical composition of milk supplied to canteens of various hospitals in Faisalabad City, Pak. J. Zool., 9:139-142.

[14] Li, Z., L. L. Wu, Y. P. Wang, A. M Liu, C. C Zou, and Z. Y. Zhao. 2009. Melamine contaminated milk products induced urinary tract calculi in children. World Journal of Pediatrics, 5 (1): 31-35.

[15] Mota, F. J. M, F. Implvo, S. C. Cunha, M. Beatriz and P. P. Oliveira. 2003. Optimization of extraction procedures for analysis of benzoic and sorbic acids in foodstuffs. Food Chemistry, 3 (82): 469-473.

[16] Mustafa, M. I, B. B. Khan, M. Abdullah and L. A. Khan. 1991. Chemical and hygienic quality of milk supplied to canteens of various educational institutions in Faisalabad city. Pak. J. Agri. Sci., 28 (1): 9-12.

[17] Neumann, C. G., D. M. Harris and L. M. Rogers. 2002. Contribution of animal source foods in improving diet quality and function in children in the developing world. Nutr. Res., 22: 193-220.

[18] Nirwal, S., R. Pant and N. Rai. 2013. Analysis of milk quality, adulteration and mastitis in milk samples collected from different regions of Dehradun. International Journal of Pharm Tech Research, Vol.5, No.2, pp 359-364.

[19] Rideout, T. C., Q. Liu, P. Wood and M. Z. Fan. 2008. Nutrient utilization and intestinal fermentation are differentially affected by the consumption of resistant starch varieties and conventional fibers in pigs. British Journal of Nutrition, (99), 984-92.

[20] Saad, B., M. F. Bari, M. I. Saleh, K. Ahmad and M. K. M. Talib. 2005. Simultaneous determination of preservatives in food stuffs using HPLC. Journal of Chromatography Analysis, (1073), 2005, 393.

[21] See, A. S., A. B. Salleh, F. A. Bakar, N. A. Yusof, A. S. Abdulamir and L.Y. Heng. 2010. Risk and health effect of boric acid. American Journal of Applied Sciences, 620-627.

[22] Singuluri, H and M. K. Sukumaran. 2014. Milk Adulteration in Hyderabad, India -A Comparative Study on the Levels of Different Adulterants Present in 


\section{International Journal of Science and Research (IJSR) \\ ISSN (Online): 2319-7064 \\ Index Copernicus Value (2013): 6.14 | Impact Factor (2015): 6.391}

Milk. J Chromat Separation Techniq., ISSN: 2157-7064 JCGST, an open access journal.

[23] Tipu, M. S., I. Altaf, M. Ashfaq and Siddique. 2007. Monitoring of chemical adulterants and hygienic status of market milk. Handbook published by Quality Control Laboratory, University of Veterinary and Animal Science, Lahore, Pakistan. pp. 7.
[24] Walker, G. P., Dunshea, F. R. and Doyle, P. T. 2004. Effcts of nutrition and management on the production and composition of milk fat and protein. Australian Journal of Agriculture Research, (55): 1009-1028.

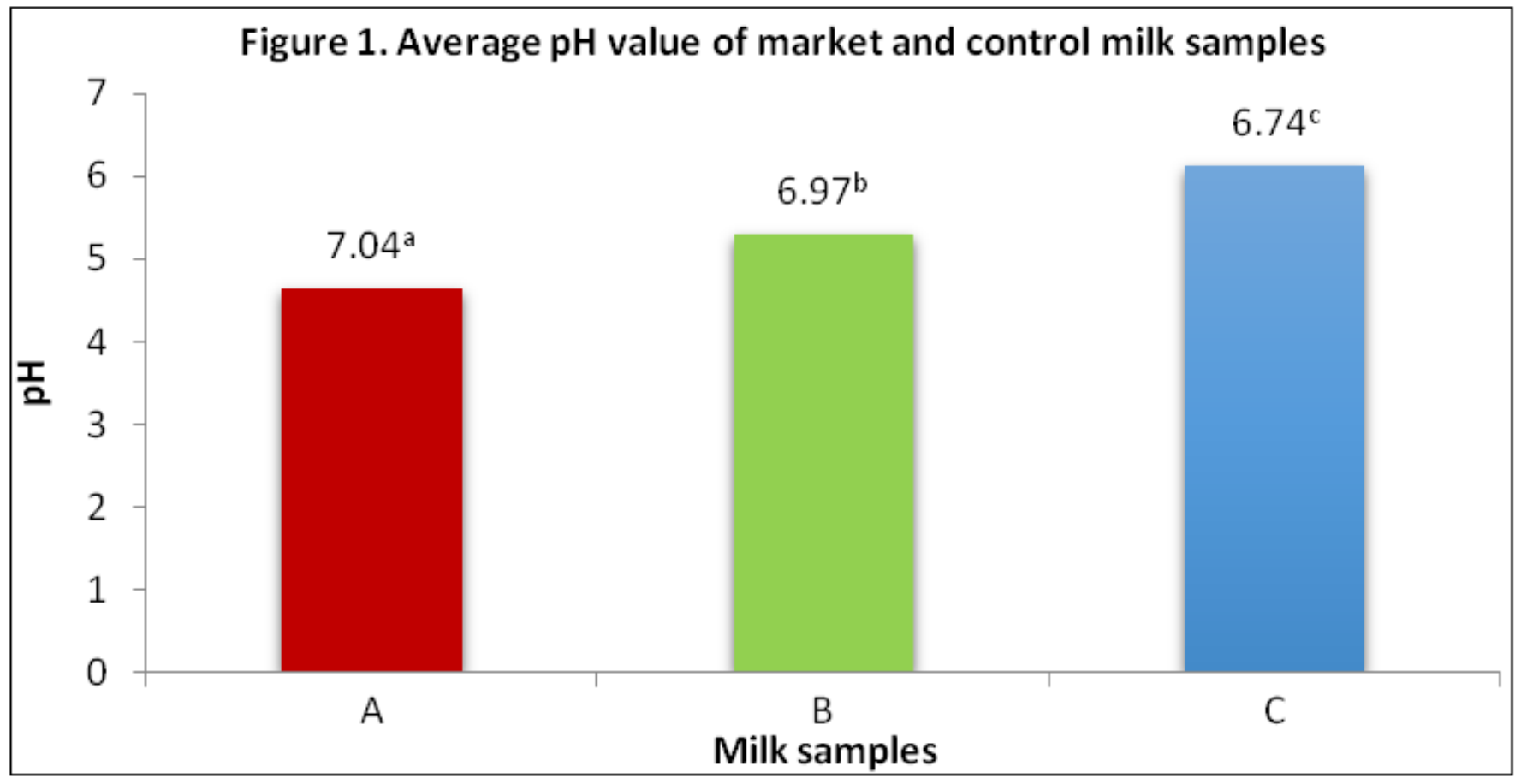

$\mathrm{SE} \pm=0.0008$

$\operatorname{LSD}(0.05)=0.01$

$A=$ Milk samples from Hyderabad City

$\mathrm{B}=$ Milk samples from outskirts of Hyderabad

$\mathrm{C}=$ Whole milk samples/ Control

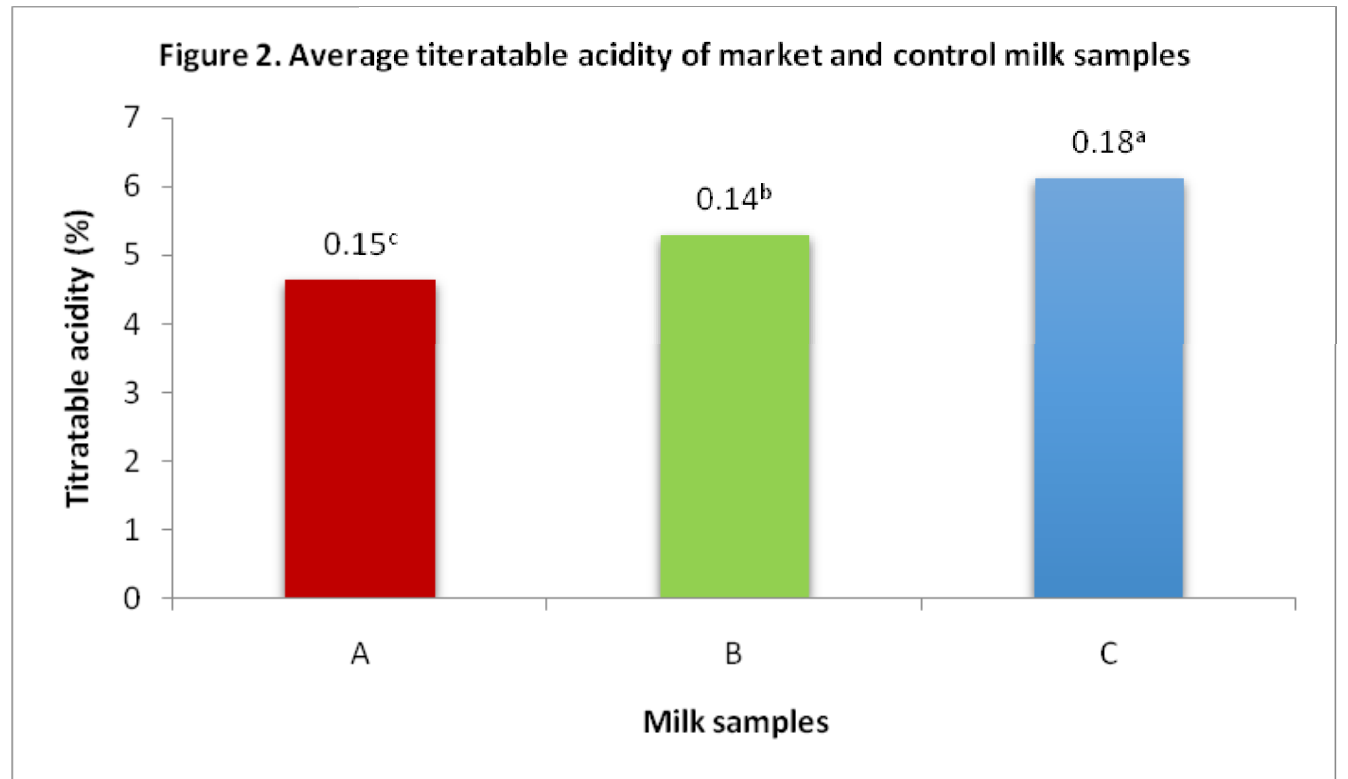

$\mathrm{SE} \pm=0.0001$

$\operatorname{LSD}(0.05)=0.0003$

A= Milk samples from Hyderabad City

$\mathrm{B}=$ Milk samples from outskirts of Hyderabad

$\mathrm{C}=$ Whole milk samples/ Control 


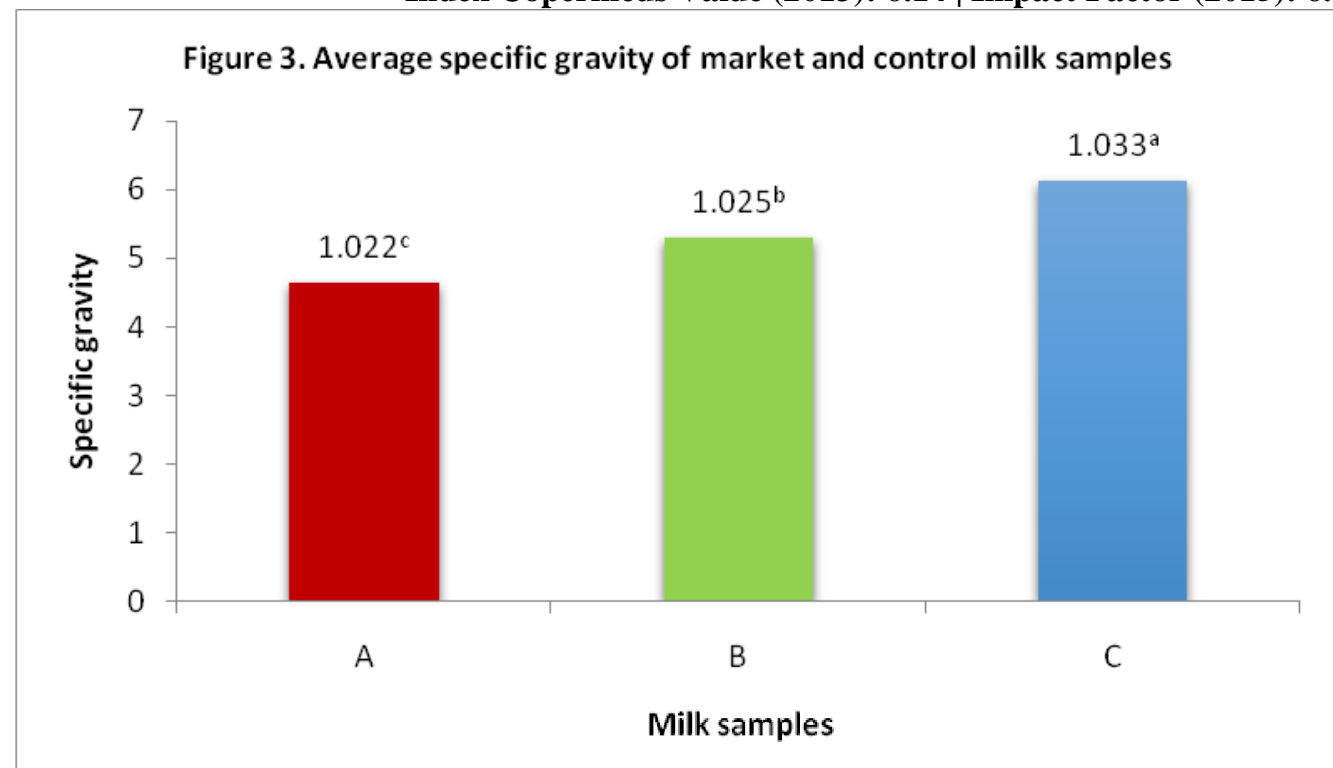

$\mathrm{SE} \pm=0.00004$

LSD (0.05) $=0.00005$

A= Milk samples from Hyderabad City

$\mathrm{B}=$ Milk samples from outskirts of Hyderabad

$\mathrm{C}=$ Whole milk samples/ Control

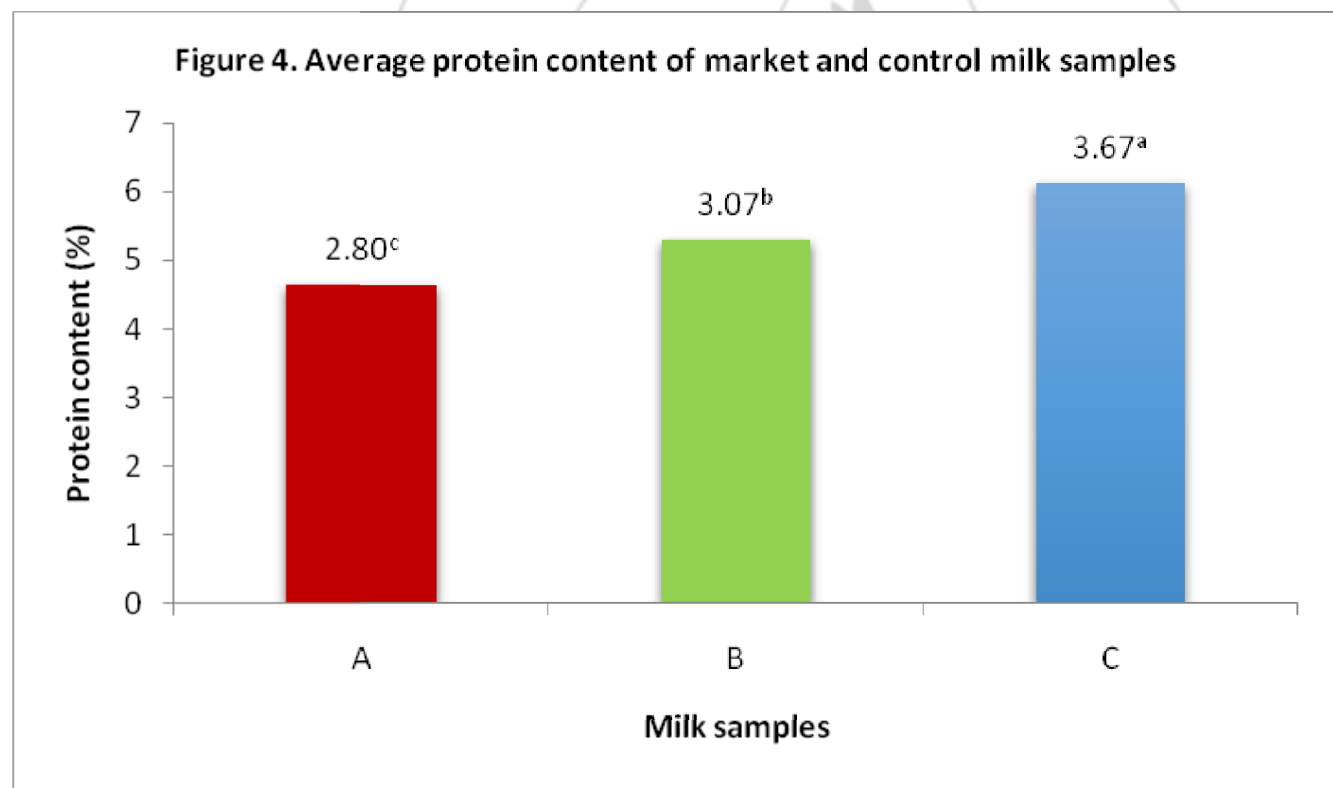

$\mathrm{SE} \pm=0.03$

$\operatorname{LSD}(\mathbf{0 . 0 5})=0.07$

$\mathrm{A}=$ Milk samples from Hyderabad City

$\mathrm{B}=$ Milk samples from outskirts of Hyderabad

$\mathrm{C}=$ Whole milk samples/ Control 


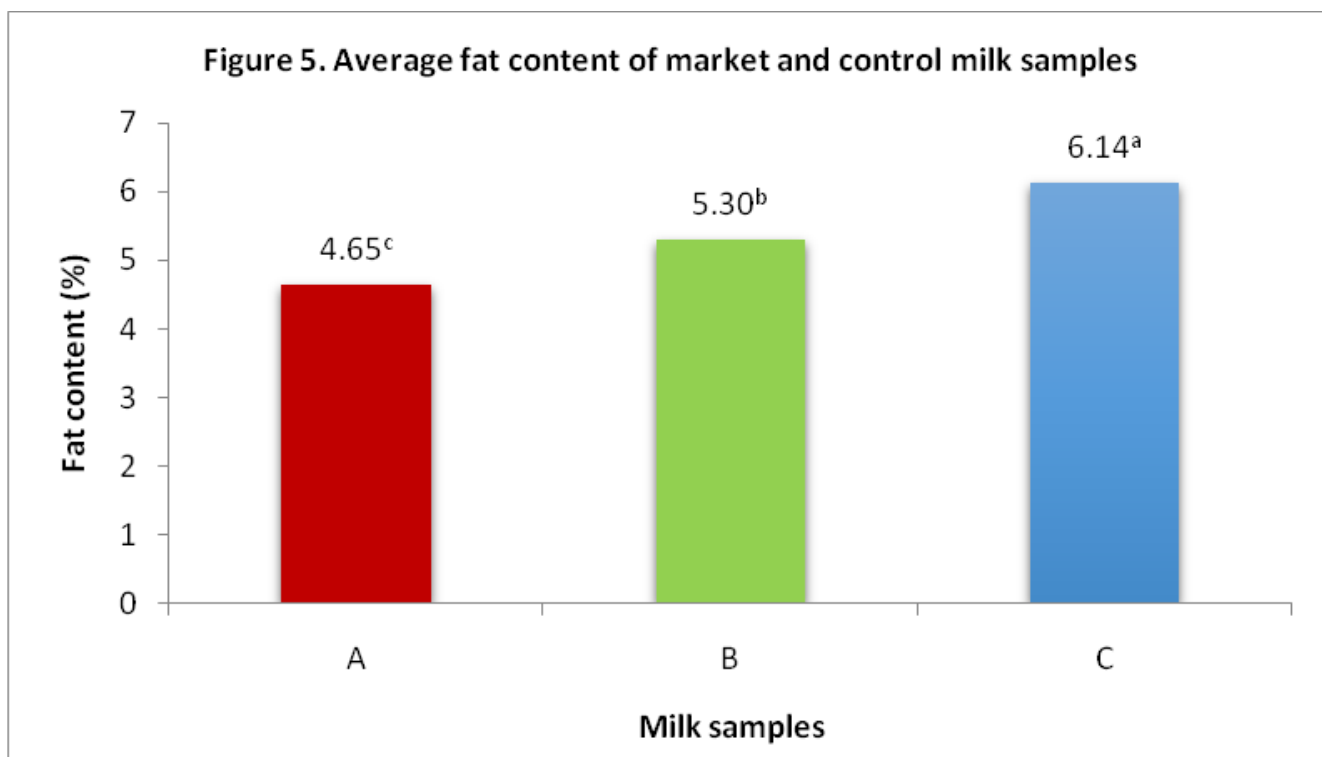

$\mathrm{SE} \pm=0.1$

$\operatorname{LSD}(0.05)=0.2$

A= Milk samples from Hyderabad City

$\mathrm{B}=$ Milk samples from outskirts of Hyderabad

$\mathrm{C}=$ Whole milk samples/ Control 